Scott C. Speal

Pennsylvania State University, USA

sspeal@yahoo.com

UDK 902.01:572.781(497.11)"2001/2005”

Izvorni naučni članak

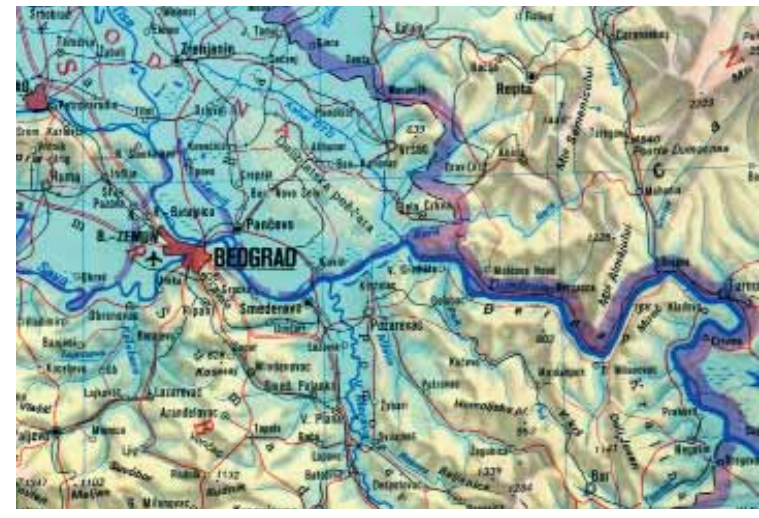

Viminacium, Stari Kostolac, Srbija

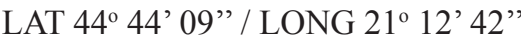

\title{
EVALUATING INTERCOSTAL VARIABILITY IN STERNAL RIB ENDS FOR PURPOSES OF SKELETAL AGING
}

\begin{abstract}
Chronological changes in sternal rib morphology have long been known to have applications for determination of skeletal age. Unfortunately, this technique has seen limited application in some circles due to a perception that it is only applicable to the fourth rib. This study demonstrates a reasonable consistency in sternal rib morphology within individuals from an archaeological collection recently excavated from the site of Pirivoj at Viminacium, Serbia. It thereby reveals that identification of the fourth rib is not necessary and, in fact, development of a method that considers multiple rib scores from the same individual is likely to improve the accuracy of the technique.
\end{abstract}

\section{Key words: Skeletal Aging techniQues, sternal RibS}

Chronological changes in the morphology of the sternal end of the fourth rib have been known to have applications for the determination of skeletal age since at least the mid-1980's1. Subsequent tests of this method have demonstrated the viability of the approach across sex and race2. It has even been shown that this technique performs better than pelvic methods for some age groups3. Unfortunately, the technique has seen fairly limited application in some circles due to a perception that it is only applicable to the fourth rib, which can be difficult to identify in archaeological or incomplete assemblages. The develop-

1 Iscan et al. 1984, 1985; Iscan and Loth 1986.

2 Dudar et al. 1993.

3 Russell et al. 1993. ers of the method, however, provide no explicit reason for their selection of the fourth rib as an age indicator. The choice appears to have been an arbitrary one designed to minimize the effects of variability between ribs in morphological change.

This study therefore attempts to demonstrate consistency in age-related morphological changes of the sternal end across the ribs within individuals from an archaeological collection. The assemblage employed was recovered from the necropolis of Pirivoj at Viminacium - a provincial Roman urban center located in Eastern Serbia along the Danube River - between 2001 and 2005. The present test was conducted on an archaeological assemblage in order to examine its performance under taphonomic conditions in 
which there has been considerable post-depositional breakage. A clinical collection is not necessary for purposes of studying morphological variability within individuals, as true chronological age is not at issue. The Viminacium assemblage was a good candidate for the study because bone preservation at the site is good, and most of the skeletons recovered had been placed in individual graves, which eliminated the problem of commingled ribs from multiple persons. Any ribs that could not be confidently be attributed to a particular individual were not included in the study. The results demonstrate that identification of the fourth rib is not necessary and, in fact, development of an approach that makes use of multiple rib scores from the same individual is likely to improve the accuracy of the technique.

\section{METHOD}

In the Iscan Method, specimens are scored into 9 distinct phases (0-8) based on changes noted in the form, shape, texture, and overall quality of the sternal facet4. Metamorphosis begins with the formation of an indentation (pit) in the medial articular surface of the rib. This is initially a small amorphous depression in the previously flat, billowy endplate. As the pit deepens, the indentation

\footnotetext{
4 For more comprehensive summaries of the method see
} Burns 1999:57 or Bass 2005:136-41 between the anterior and posterior walls takes on a V-shaped appearance that gradually widens into a U-shape. With increasing age, the pit becomes wider and deeper. The rim of the pit progresses from a regular, rounded border to a thinner one with a scalloped edge, but with a still fairly even margin. At advanced age, the rim grows increasingly sharp and irregular. The texture and density of the bone itself, smooth and solid in youth, begins to deteriorate until the bone becomes thin, brittle and porous in the elderly.

\section{ANALYSIS}

For this study, all intact sternal rib ends from the collection were scored according to the criteria outlined in the Iscan method. Several examples are presented here to clarify the procedure. Six ribs, for instance, from male specimen G152 from the site of Pirivoj were scored to phases 2 or 3, associated with an age range of 20.8-27.75 by Iscan (Figure 1). This individual was otherwise estimated to be between 20 and 44 on the basis of the pelvis symphyseal joints. Note the shallow central depression and thick, scalloped edges.

Six ribs from male individual G184 were scored 3-4, associated with an age range of 24.1 - 30.6 in the Iscan system (Figure 2). This individ-

5 All age ranges in the Iscan technique are calculated to a $95 \%$ confidence interval

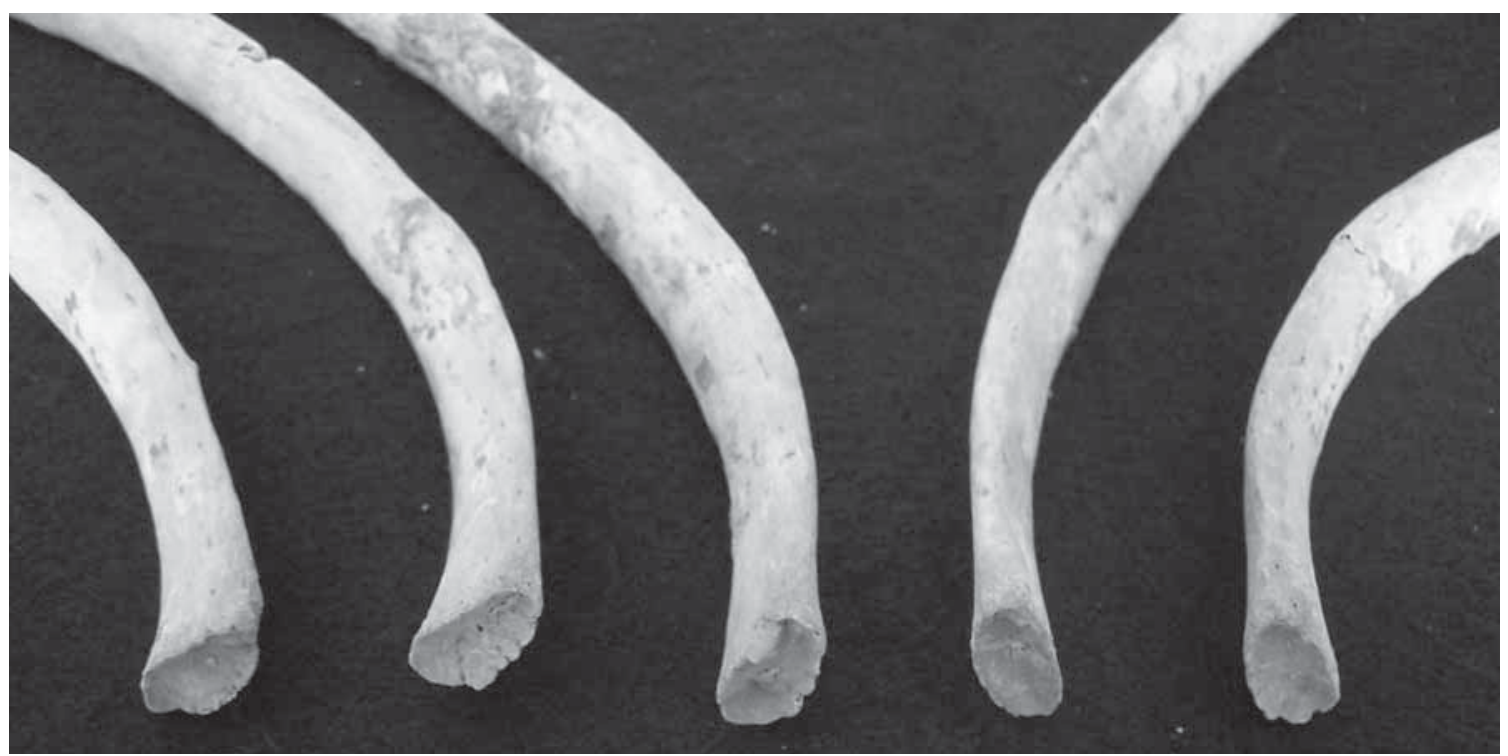

Figure 1: Five of the Six Ribs Scored from PIR G152. Note shallow central pit and scalloped edges 


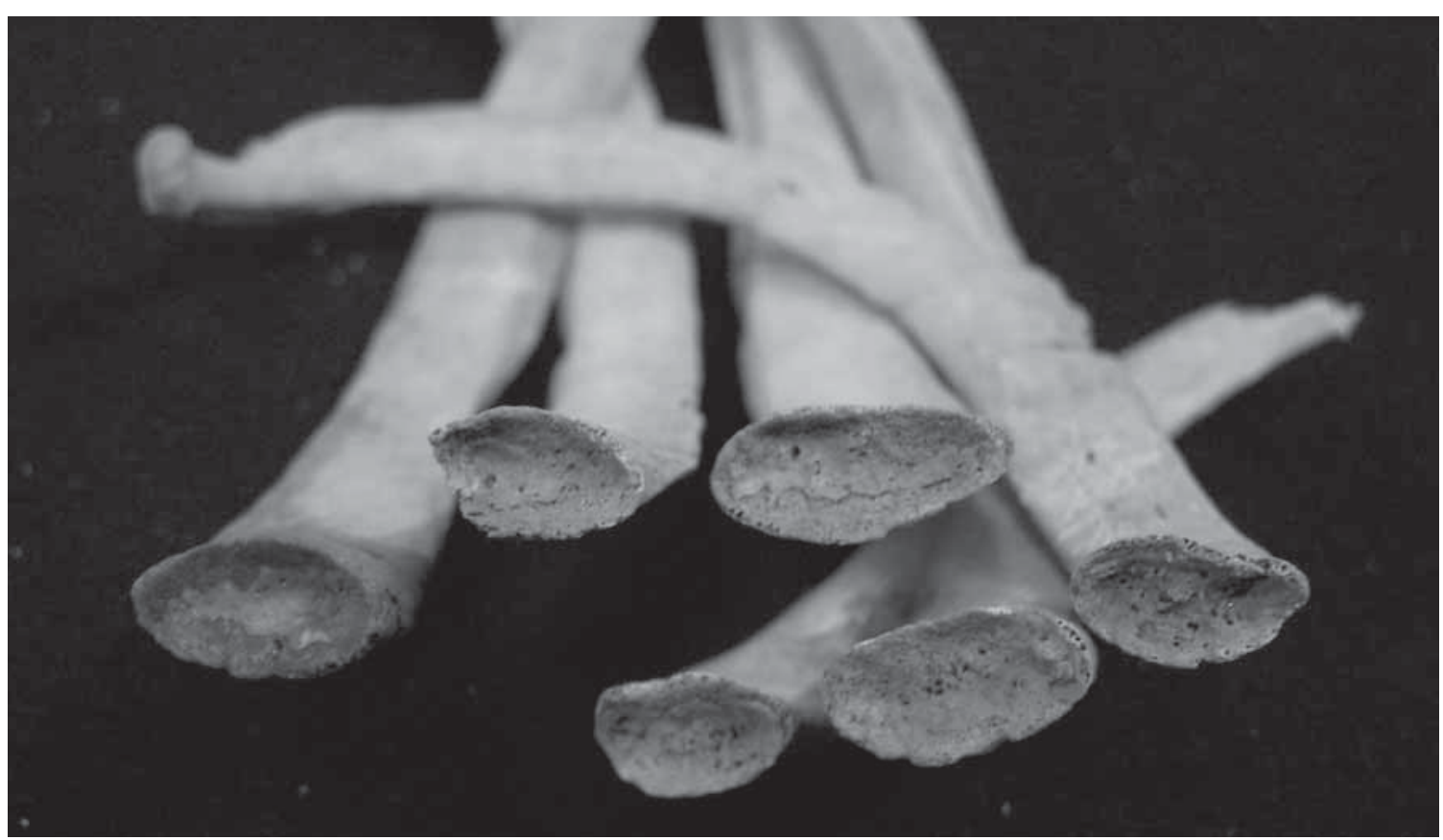

Figure 2: Ribs Scored from Individual PIR G184. Note deepening depression with incipient porosity and thinning edges that lack scalloping.

ual's age was otherwise estimated to be between died at between $25-78$ years of age. Note irregu$25-42$ on the basis of auricular surface morphology. Note deepening depression with incipient porosity and thick edges that lack scalloping.

Seven ribs from female individual G121 were all scored as a 6 on the Iscan system (Figure 3). This score is associated with an age range of 43.3 - 58.1 by Iscan. On the basis of pelvic morphology, this individual was estimated to have lar projections of bone and increased porosity inside the central depression.

Five ribs from individual G61 were examined (Figure 4). Two were scored phase 6 and three (including both 1 st ribs) to phase 7 , associated with a combined age range of $44.3-64.1$ in the Iscan system. This individual's age was otherwise estimated to be between 26 and 59 years of

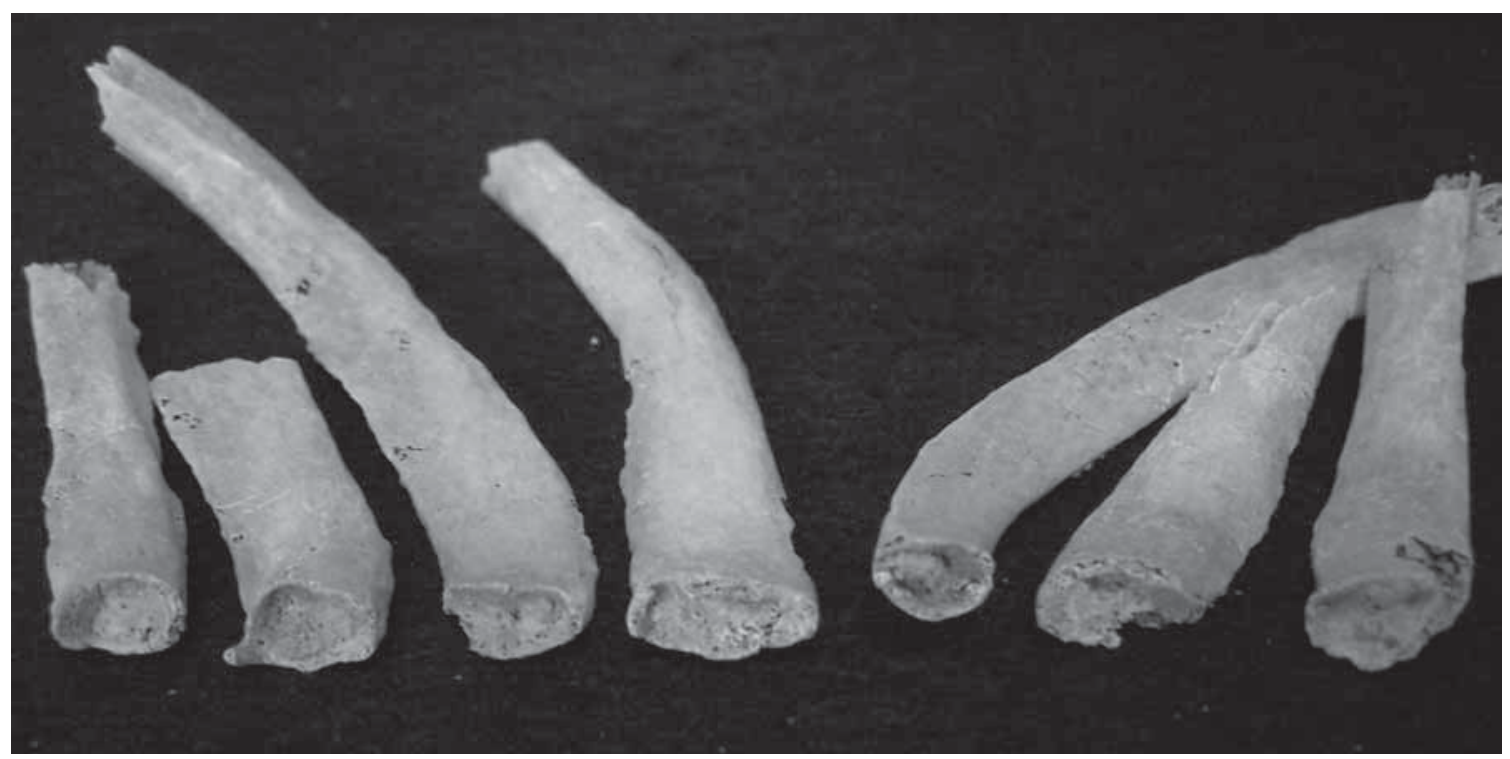

Figure 3: Ribs Scored from Individual PIR G121. Note irregular projections of bone and increased porosity inside the central depression. 


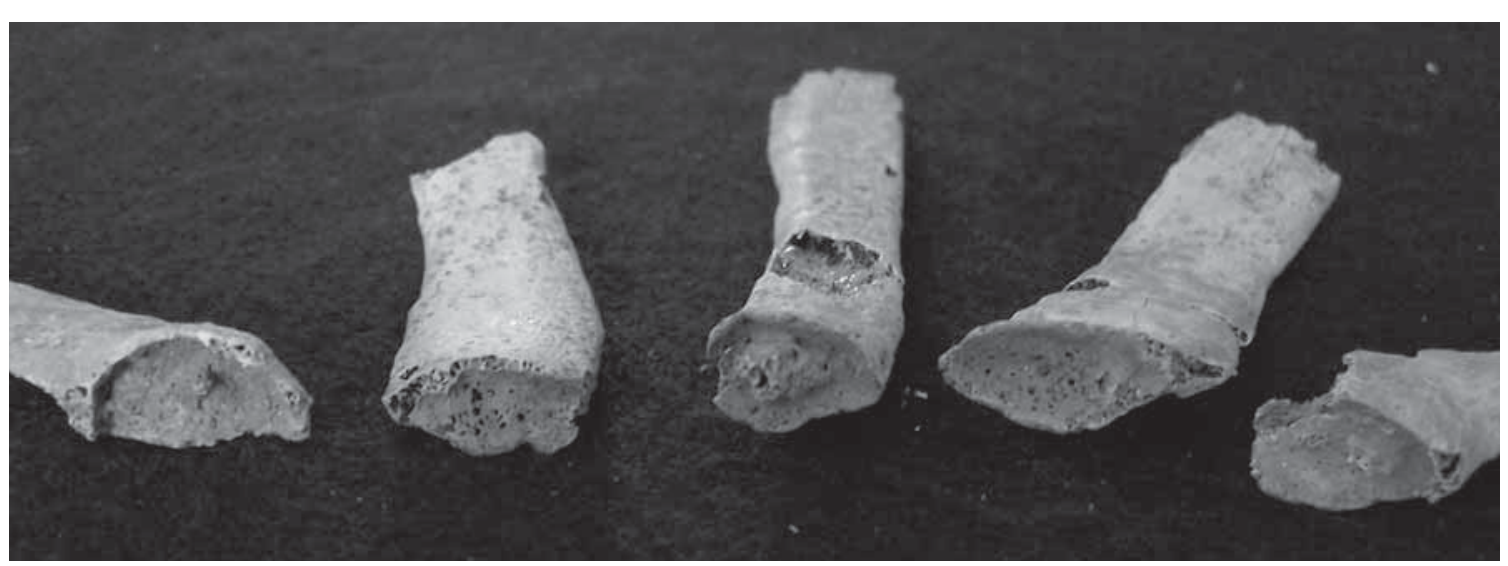

Figure 4: Ribs Scored from Individual G61. Note the irregular, porous central interior and thin, irregular edges of the specimen on the far left.

age on the basis of the pelvic joints. Note the irregular, porous central interior and thin, irregular 'crab-claw' appearance of the edges.

\section{RESULTS}

337 sternal rib ends derived from 58 individuals for which multiple scores could be obtained were examined (out of a sample population of 168). It was not possible to document the presence of the 4th rib in most cases due to the fragmentary condition of the assemblage. In only four instances could its presence be confirmed. The laws of probability, however, allow the number of 4th ribs included in the study to be estimated at between 27 and $50(a=.05, z=1.96)$. This range is sufficiently high to infer that fourth ribs composed a substantial proportion of the sample.

The range of scores within any one individual showed a fairly strong degree of consistency. Only three individuals $(5.2 \%)$ produced discontinuous (i.e. ribs from non-sequential) age phases, and these were always a product of the 1st rib. Nine $(15.5 \%)$ manifested morphology characteristic of three consecutive age phases. Thirty-three (56.9\%) were scored into two consecutive phases and $13(22.4 \%)$ were scored into a single phase. Furthermore, both the 2nd and 10th ribs were found to agree with the rest of each assemblage in the majority $(87.5 \%, \mathrm{n}=18)$ of the cases in which they were identified. Only the 1 st rib manifested a high proportion $(46.6 \%, \mathrm{n}=30)$ of disagreement or scored to a non-consecutive age phase.

The variability in rib scores was further examined using regression analysis by plotting the scores against a point estimate for age obtained from the midpoint of each phase weighted by the number of ribs falling within that phase. These were modeled by estimated sex in order to check for any biasing patterns related to that variable. None were found. The results show that the relationship between rib score and skeletal age $(\mathrm{s}=0.799, \mathrm{r} 2=85.1)$ was not purely linear, with an obvious increase in variance at higher ages (Figure 5). A logarithmic remedial measure, however, produces a more coherent model $(\mathrm{s}=0.661$, $\mathrm{r} 2=89.8$ ). By eliminating the 1 st rib scores, one obtains a substantially lower standard deviation and higher coefficient of determination ( $\mathrm{s}=0.517$, r2 =93.3)(Figure 6). Excluding scores for the 2nd and 10th ribs provides only minimal further benefit to the model ( $\mathrm{s}=0.508, \mathrm{r} 2=93.7)$.

\section{CONCLUSIONS}

Even when scored to two or three consecutive phases, the rib age results were often more precise than those obtained from either the pubic symphysis or auricular surface alone. The standard deviation of rib scores within any individual when all ribs except the first are considered is 0.517 phases, meaning that ribs fell within a two phase range about $95 \%$ of the time $(t=2.077$, d.f. $=58$ ). The present results are consistent with those of earlier studies that also found no significant intercostal variation between the 'typical' (3rd-9th) ribs, and suggest that it is reasonable to extend the principle to the 2nd and 10th ribs as well. These results imply that identification of the fourth rib is not necessary and, in fact, development of an approach that makes use of multiple rib scores from 


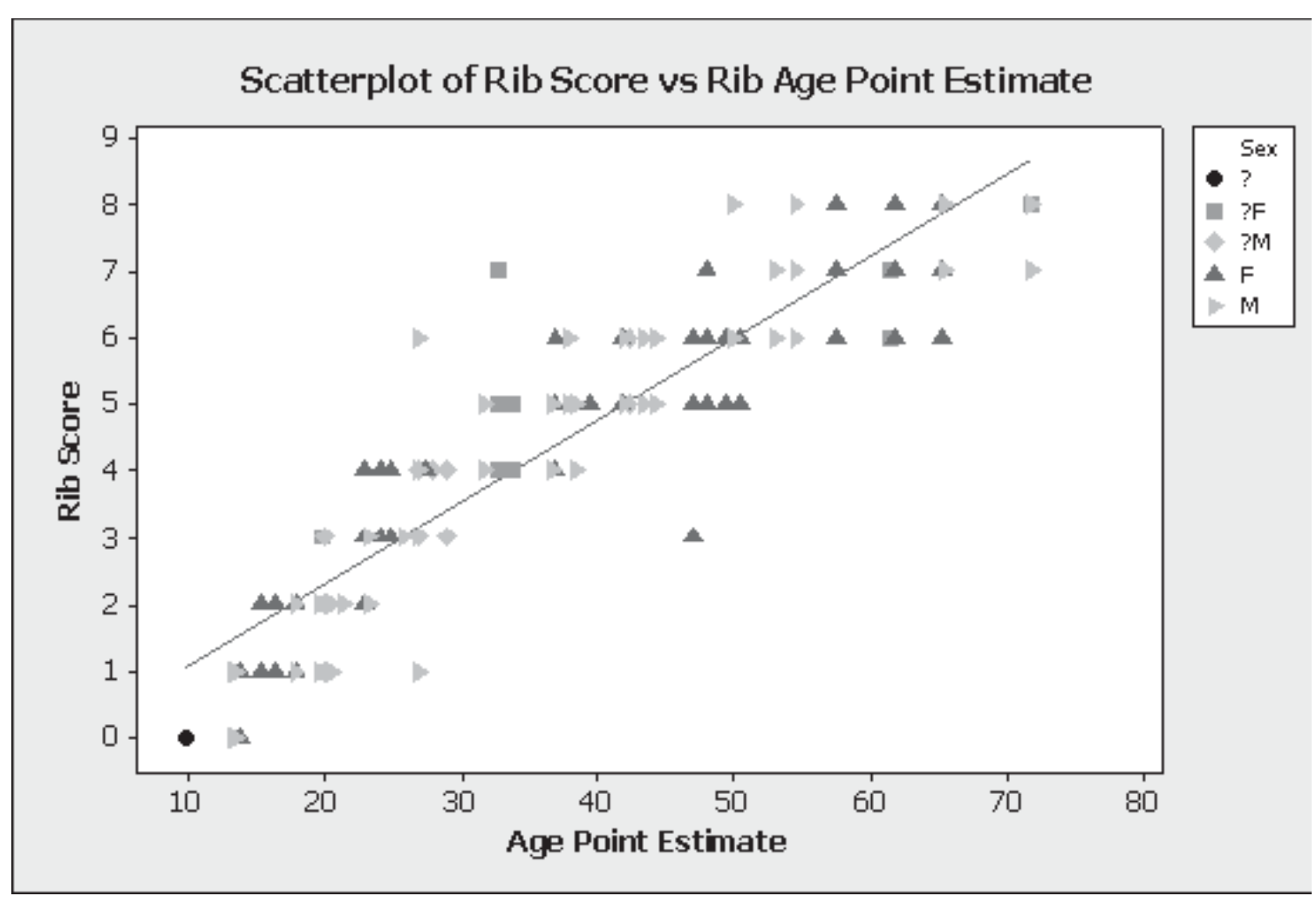

Figure 5: Scatterplot of Rib Score versus Age at Death Point Estimate Derived from Ribs.

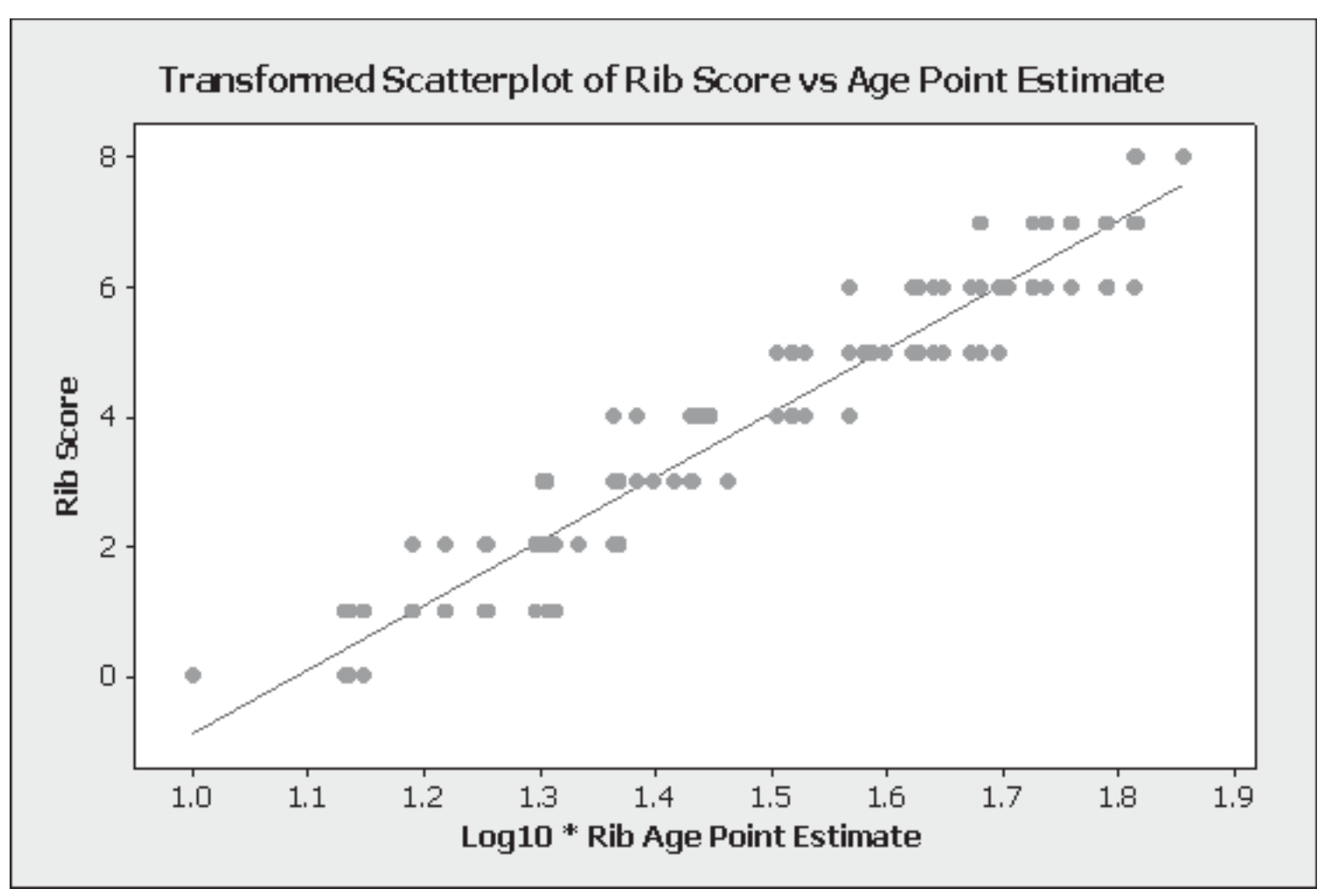

Figure 6: Transformed Scatterplot of Rib Score Versus Point Estimate with 1st Ribs Removed. 
the same individual is likely to improve the accuracy of the technique - if by somewhat decreasing its precision.

\section{ACKNOWLEDGEMENTS}

This research was funded by an Individual Advanced Research Opportunities grant from the International Research and Exchanges Board (IREX), a Grant-in-aid of Research from the Sigma Xi Scientific Research Society, and a Hill Foundation grant from the Department of Anthropology at the Pennsylvania State University.

\section{REFERENCES}

\section{Bass 2005}

Bass, Willam M. Human Osteology: A Laboratory and Field Manual. $5^{\text {th }}$ Edition. Special Publication No. 2 of the Missouri Archaeological Society, Colombia, MO. 2005

\section{Burns 1999}

Burns, Karen R. Forensic Anthropology Training Manual. Prentice-Hall. Saddle River NJ. 1999.

\section{Dudar 1993}

Dudar, J. Christopher, Identification of Rib Number and Assessment of Intercostal Variation at the Sternal Rib End. Journal of Forensic Sciences 38:788-97, 1993

\section{Dudar et al. 1993}

Dudar, J. Christopher, Susan Pfeiffer, and Shelley Saunders, Evaluation of Morphological and Histological Adult Skeletal Age-at-Death Aging Techniques Using Ribs. Journal of Forensic Sciences 38:677-85, 1993

\section{Iscan and Loth 1986}

Iscan, M. Yasar, and Susan Loth, Estimation of Age and Determination of Sex from the Sternal Rib. In Forensic Osteology: Advances in the Identification of Human Remains, edited by Kathleen J. Reichs, pp. 68-89. Charles C. Thomas, Springfield IL. 1986.

\section{Iscan et al. 1985}

Iscan, M.Y., S. R. Loth, and R. K. Wright, Age estimation from the rib by phase analysis: White females. Journal of Forensic Sciences 30:853--63, 1985.

\section{Iscan et al. 1984}

Age estimation from the ribs by phase analysis: White males. Journal of Forensic Sciences 64:53-57, 1984.

\section{Russell et al. 1993}

Russell, Katherine F., Scott W. Simpson, Jeremy Genovese, Mary D. Kinkel, Richard S. Meindl, and C. Owen Lovejoy. Independent Test of the Fourth Rib Aging Technique. American Journal of Physical Anthropology 92:53-62, 1993.

\section{Yoder et al. 2001}

Yoder, Cassady, Douglas H. Ubelaker, and J. F. Powell. Examination of Variation in Sternal Rib End Morphology Relevant to Age Assessment. Journal of Forensic Sciences 46:223-27. 2001.

\section{VREDNOVANJE INTERKOSTALNOG VARIJABILITETA STERNALNIH OKRAJAKA REBARA U CILJU ODREĐIVANJA STAROSTI SKELETA}

Odavno je poznato da hronološke promene oblika sternalnih okrajaka rebara mogu da posluže za određivanje starosti skeleta. $\mathrm{Na}$ žalost, ova tehnika je imala ograničenu primenu, jer se smatralo da se ona može primeniti samo na četvrto rebro. U ovom tekstu se pokazuje da kod individua iz arheološke zbirke nedavno iskopane na lokalitetu Pirivoj na Viminacijumu u Srbiji, postoji smislena doslednost u morfologiji sternalnih okrajaka. U njemu se obrazlaže da nije neophodna identifikacija četvrtog rebra i da zapravo razvoj metode koja obuhvata višestruke skorove rebara iste individue može poboljšati tačnost ove tehnike.

KLJUČNE REČI: STAROST SKELETA, TEHNIKE, STERNALNI OKRAJAK REBARA 